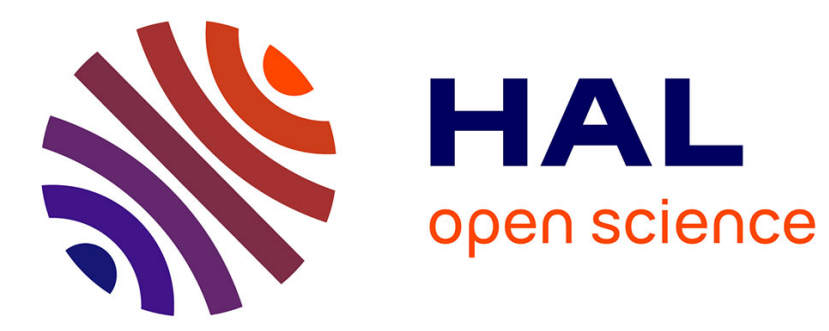

\title{
Heavy duty gas turbines experience with ash-forming fuels
}

\author{
M. Molière, J. Sire
}

\section{To cite this version:}

M. Molière, J. Sire. Heavy duty gas turbines experience with ash-forming fuels. Journal de Physique IV Proceedings, 1993, 03 (C9), pp.C9-719-C9-730. 10.1051/jp4:1993975 . jpa-00252417

\section{HAL Id: jpa-00252417 https://hal.science/jpa-00252417}

Submitted on 1 Jan 1993

HAL is a multi-disciplinary open access archive for the deposit and dissemination of scientific research documents, whether they are published or not. The documents may come from teaching and research institutions in France or abroad, or from public or private research centers.
L'archive ouverte pluridisciplinaire HAL, est destinée au dépôt et à la diffusion de documents scientifiques de niveau recherche, publiés ou non, émanant des établissements d'enseignement et de recherche français ou étrangers, des laboratoires publics ou privés. 


\title{
Heavy duty gas turbines experience with ash-forming fuels
}

\author{
M. Molière $\left({ }^{1}\right)$ and J. Sire $\left({ }^{2}\right)$ \\ (1) European Gas Turbines SA (EGT SA), France \\ $\left(^{2}\right)$ Gec Alsthom, Belfort Research Center (CERM), France
}

\begin{abstract}
The heavy duty gas turbines operating in power plants can burn various fuels ranging from natural gas to heavy oils. Ash-forming fuels can have detrimental effects on the turbine hardware such as: combustion troubles, erosion, corrosion and fouling by ashes. For decades, progress has been made by the gas turbine industry, especially in the fields of superalloy metallurgy, coating and cooling technology. Furthermore, fuel treatments inspired by the petroleum and marine-engine industries (electrostatic and centrifuge desalting systems) and a vanadic corrosion inhibition philosophy based on magnesium additives have been developed to fully control corrosion.
\end{abstract}

\section{The heavy duty gas turbine as a rising prime-mover.}

A number of technical and economical reasons account for the increasing part played by the stationary gas turbine on the power generation scene: regular improvements in performances [1]; versatility in electric applications [2]; fair compliance with environmental regulations [3] and fuel flexibility.

Contrary to the aircraft and aero-derived engines that burn exclusively "clean" light distillates, the heavy duty machine is called to handle a wide variety of fuels including: light hydrocarbons (natural gas, LPG's, etc.); process gases (coke-oven gas, refinery flare gas, coalderived gas [4], biogas); true petroleum distillates and ash-forming fuels (petroleum crude oils, heavy oils and blended residual oils).

\section{The consequences of fuel flexibility.}

Gas turbine components designed to operate on ash-forming fuels must exhibit not only advanced strength and oxidation properties but also high combustion performances and outstanding hot corrosion resistance. In fact, this category of fuel is likely to produce three main adverse effects on the hot gas path hardware: i) erosion due to impinging particles; ii) hot corrosion by fusible slags and iii) fouling by solid ash deposits.

During the past decades a new technology of heavy fueled machines has emerged in the gas turbine industry to cope with such challenging requirements while suitable fuel oil treatments, mainly inspired by the petroleum industry practices have been concurrently developed as complementary means to fully control the hot corrosion threat [5]. 


\section{Hot gas path materials to date: an overview [6].}

1) The first stage nozzles (or "stator vanes", Fig. 1) undergo the highest temperatures and thermal shocks. The cobalt-base FSX 414 super-alloy used by the General Electric Co. of U.S.A. (GE) and EGT SA ensures an outstanding oxidation/corrosion resistance and an excellent weldability. A new nickel-base alloy, designated GTD222 and having a better creep strength than FSX414 has been recently introduced on the second and third stage nozzles of the EGT SA/GE class $\mathrm{F}$ turbines.

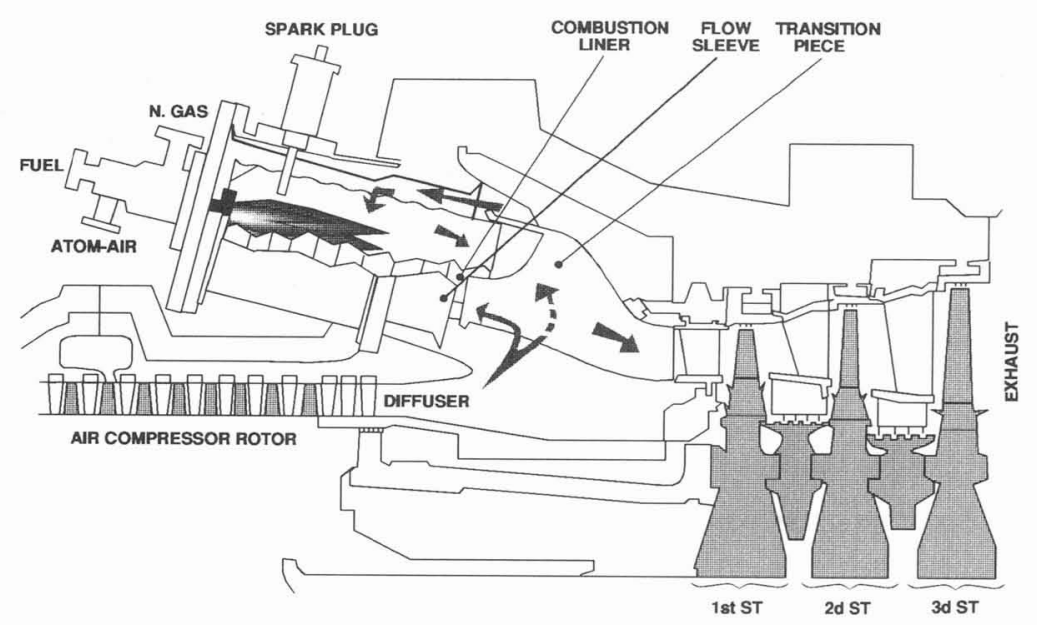

Fig. 1. - Shematic section of a $6000 \mathrm{~B}$ hot gas path.

2) The first stage buckets are subjected to the most arduous combination of thermal and mechanical stresses (centrifugal forces). IN738, a nickel-base chromium-rich alloy incorporating oligo-elements like $\mathrm{W}, \mathrm{Nb}, \mathrm{Ta}$ is being used successfully not only for the first stage buckets but also for most of the turbine buckets. Now GTD 111 derived from current aircraft blade metallurgy and permitting an extra $20^{\circ} \mathrm{C}$ increase in firing temperature is replacing IN738 on the first stage buckets. It has been the subject, with respect to IN738, of extensive $\mathrm{lab}$ tests and a theoretical approach to optimize the additions of $\mathrm{Cr}, \mathrm{Co}, \mathrm{Mo}, \mathrm{W}, \mathrm{Ta}, \mathrm{Al}$.

3) The coatings used by EGT SA are: platinium-aluminium diffusion coatings (RT22) and overlay coatings (V.P.S.: vacuum plasma sprays). The beneficial catalytic role played by platinium in the formation of a refractory, very adherent and erosion-resistant alumina scale in diffusion coatings has been early recognized. While in a diffusion coating at least one of the major constituents ( $\mathrm{Ni}$ in IN738) is supplied by the metal substrate, all the constituents of an overlay coating are supplied from external sources. Consequently much wider actual coating compositions can be tested and the most efficient one selected. VPS is now one of the most advanced coating processes.

4) Ceramics are applied as thermal barrier coatings ( $\mathrm{NiCrAlY}+\mathrm{Y}_{2} \mathrm{O}_{3}$ stabilized $\mathrm{ZrO}_{2}$ ) in the combustion hardware (liners; transition pieces) in order to decrease metal skin temperatures and consequently increase thermal fatigue life. 
5) Air-cooling plays a paramount role in modern machines [1]: in the "Frame 6" machine, for instance, the first and second stage buckets and nozzles are air-cooled; another important feature is the film-cooling of the internal walls of the combustion liners by the combustion air that is reverse-flow distributed to the combustion chambers (Fig. 1).

\section{An insight into the chemistry of petroleum fuels.}

Crude oils are basically mixtures of organic liquids that contain carbon and hydrogen as major elements (respectively $84-86 \%$ and $12-14 \%$ ) but that display, due to their fossil origins, an infinity of molecule sizes and structures as well as a rich variety of oligo- and trace elements (S, O, N, P, V, Ni, Cr, Fe, Na, K, Ca, Mg, Al, Si, Ba, etc.).

These elements, though present in lower amounts, are important in the general chemistry of the crude and ash-forming oils. Indeed, due to their high boiling points, most of them concentrate in the "bottom of the barrel" during the refining processes and reach troublesome concentrations in the heavy oils.

The asphaltenes are complex molecules with high molecular weights (up to $500 \mathrm{~g} / \mathrm{mole}$; Fig. 2) [7]. They need close attention during both the handling and the combustion processes of a power plant, due in particular to their tendency to floculate, to their differential solubilities in oils of different origins and to their slow-burning properties.

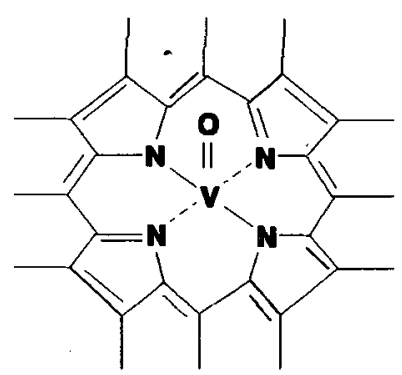

a - THE STRUCTURE OF PORPHYRINS

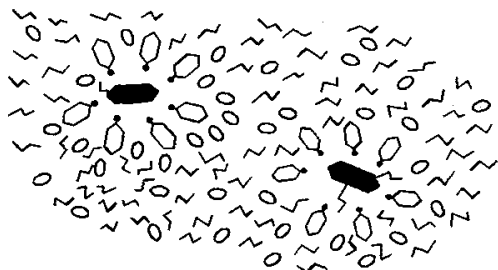

b - THE ASPHALTENE/RESIN INTERACTION

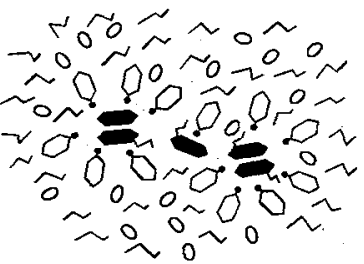

- THE INTER-MOLECULAR ASSOCIATIONS BETWEEN ASPHALTENE MOLECULES ASPHALTENES (polycyclic nucieus \& allphatic chalns) RESINS AROMATIC HYDROCARBONS PARAFFINIC AND/OR NAPHTENIC HYDROCARBONS

Fig. 2. - The asphaltenes in fuel oils.

Vanadium, nickel and iron are the core elements of the organo-metallic porphyrins usually forming part of the asphaltene molecules (Fig. 2). Vanadium produces corrosive ashes; its concentration in crude oils range from a few ppm (Arabian light) to $1200 \mathrm{ppm}$ (Venezuelian) and can exceed $5000 \mathrm{ppm}$ in vacuum residua. Nickel is present in lower concentrations except in certain crudes (Indonesian, Chinese, Venezuelian...). Lead, though not a normal 
component of the crude oils can be accidentally introduced in heavy oils in the form of TEL or TML (tetra-ethyl and tetra-methyl lead) that are conventional anti-knock additives of the gasolines.

The minor non-hydrocarbon species are emulsified water and suspended inorganic solids. The water, that contains alkaline and earth-alkaline metals $(\mathrm{Na}, \mathrm{K}, \mathrm{Ca}, \mathrm{Mg})$ comes from the oil-fields (the connate waters and the injection brines contain up to $60000 \mathrm{ppm}$ of $\mathrm{NaCl}$ by weight) or from ballast operations in the tankers (sea water contains around $38000 \mathrm{ppm}$ $\mathrm{NaCl}$ ).

The inorganic sediments (sand, clay, gypsum, rust) come from the oil-fields, from the fuel handling and storage facilities and possibly from the refining processes (e.g.: alumina and silica catalysts “fines” from F.C.C.'s).

\section{The formation of ashes in gas turbine combustors.}

Due to the high pressures (10 to 14 bars) and temperatures $\left(300\right.$ to $350{ }^{\circ} \mathrm{C}$ ) of the combustion air delivered by the compressor, the gas turbine develops very hot flames (2100 to $2300^{\circ} \mathrm{C}$ in the "reaction zone" or "stoichiometric zone"). Another important feature is the short residence time of the fuel molecules inside the combustors that is offset by the high excess of air ( 14 to $15 \% \mathrm{O}_{2}$ in the exhaust gases), that creates strongly oxidative conditions in the combustors.

Flames of liquid petroleum hydrocarbons are far from the simple "generators of $\mathrm{CO}_{2}+\mathrm{H}_{2} \mathrm{O}$ " considered in thermodynamical approaches:

1) The liquid fuel that is swirl-sprayed by the atomization air and projected into the flame as thin droplets begin to volatilize and the resultant vapors to burn. Some heavy hydrocarbon molecules (polyaromatics, asphaltenes) cannot burn in the oxygen depleted atmosphere around the droplets, within the short residence times available and are emitted as gaseous unburnt hydrocarbons $(\mathrm{HC})$ or further coalesce to soot particles [8];

2) sulphur (that is nil in natural gas and lower than $0.1 \%$ in aviation fuels) may reach $4 \%$ in heavy oils. In the stoichiometric zone of the flame, it is converted into SO, a very reducing species that is quickly and entirely oxidized to $\mathrm{SO}_{2}$ that is itself partly oxidized to the strongly acidic $\mathrm{SO}_{3}[8]$. Fortunately, the rate of the exothermic $\mathrm{SO}_{2}$-to- $\mathrm{SO}_{3}$ conversion is at first thermodynamically limited, in the post-flame zone of the liner (2300 down to round $1300{ }^{\circ} \mathrm{C}$ ) and then kinetically controlled when the temperature drops below $1000^{\circ} \mathrm{C}$ in the turbine (that produces gas-quenching). The net result is that the $\mathrm{SO}_{3} / \mathrm{SO}_{x}$ fraction at the exhaust $\left(530\right.$ to $590{ }^{\circ} \mathrm{C}$ ) hardly amounts to $3.5 \%$ whereas an equilibrated inter-conversion would lead to $98 \%$;

3) nitrogen can reach $0.4 \%$ in heavy oils. The passage of nitrogen-containing compounds through the combustor yields the gaseous $\mathrm{NO}_{x}$ and $\mathrm{N}_{2}$ that cross the turbine path without causing damage;

4) the alkaline metals $(\mathrm{Na}, \mathrm{K}$ ) are tolerated only as traces (less than $1 \mathrm{ppm}$ in the GE/EGT SA specification). They form trace amounts of alkali oxides and hydroxides $\left(\mathrm{M}_{2} \mathrm{O}, \mathrm{MOH}\right)$ in the flames, which entirely react with $\mathrm{SO}_{3}$ (present in relatively large excess) to form alkali sulfates $\left(\mathrm{M}_{2} \mathrm{SO}_{4}\right)$. These sulphates are stable up to $2500 \mathrm{~K}$ but have low melting points.

The earth-alkaline elements experience similar transformations but the corresponding sulfates are thermally less stable and dissociate;

5) the burned vanadium-containing porphyrins bring about $\mathrm{V}_{2} \mathrm{O}_{5}$. This oxide has a very low melting point. As a Lewis-type acid, it reacts in the post-flame zone with the alkaline and earth-alkaline sulfates to form three types of vanadates, with evolution of the volatile $\mathrm{SO}_{3}$ : 
$\mathrm{V}_{2} \mathrm{O}_{5}+\mathrm{Na}_{2} \mathrm{SO}_{4} \rightarrow 2 \mathrm{NaVO}_{3}+\mathrm{SO}_{3}:$ metavanadate; $\mathrm{MP}=630^{\circ} \mathrm{C}$,

$\mathrm{V}_{2} \mathrm{O} 5+2 \mathrm{Na}_{2} \mathrm{SO}_{4} \rightarrow 1 / 2 \mathrm{Na}_{4} \mathrm{~V}_{2} \mathrm{O}_{7}+2 \mathrm{SO}_{3}:$ pyrovanadate; $\mathrm{MP}=635^{\circ} \mathrm{C}$,

$\mathrm{V}_{2} \mathrm{O} 5+3 \mathrm{Na}_{2} \mathrm{SO}_{4} \rightarrow 2 \mathrm{Na}_{3} \mathrm{VO}_{4}+3 \mathrm{SO}_{3}$ : orthovanadate; $\mathrm{MP}=850^{\circ} \mathrm{C}$;

6) nickel is oxidized to $\mathrm{NiO}$ in the flames but contrary to $\mathrm{V}_{2} \mathrm{O}_{5}, \mathrm{NiO}$ behaves like an alkali and combines with $\mathrm{SO}_{3}$ and $\mathrm{V}_{2} \mathrm{O}_{5}$ to form $\mathrm{NiSO}_{4}\left(\mathrm{MP}=1565^{\circ} \mathrm{C}\right)$ and $\mathrm{NiV}_{2} \mathrm{O}_{6}\left(\mathrm{MP}=900^{\circ} \mathrm{C}\right)$. In the latter mixed oxide, $\mathrm{Ni}$ that "scavenges" $\mathrm{V}_{2} \mathrm{O}_{5}$, behaves as a vanadium inhibitor.

\section{The corrosivity of the ashes and the cures.}

The main corrosion problems that threaten gas turbines may be classified into sulphidation and attacks by vanadium-containing eutectics.

\subsection{SULPHIDATION CORROSION [9] (Fig. 3).}

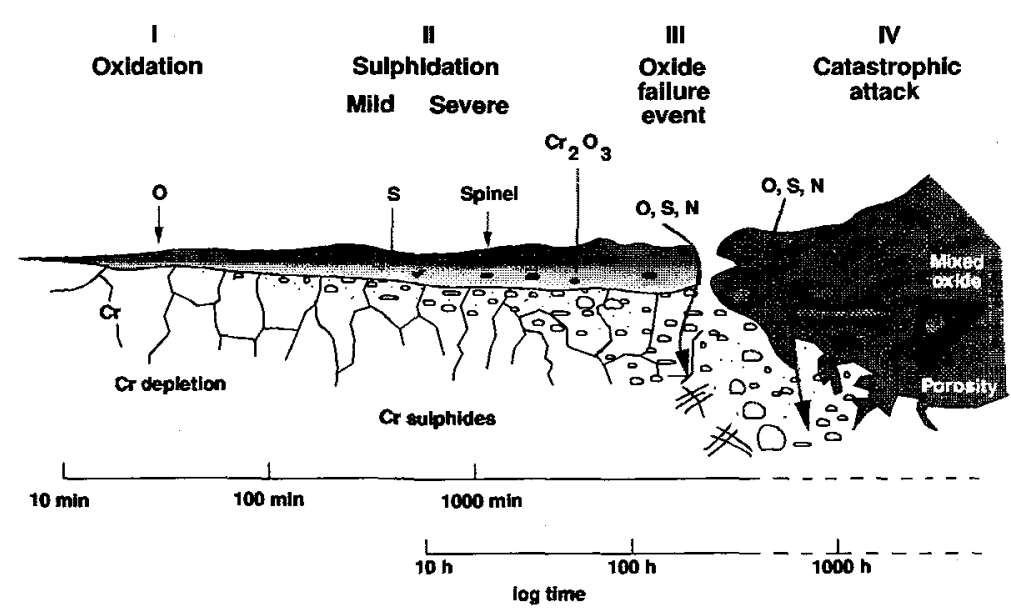

Fig. 3. - The mechanism of sulphidation.

a) The sodium sulfate that travels as thin liquid particulates in the combustion gas, impacts the nozzles and blades walls and can "film" the hottest areas. ( $\mathrm{Na}_{2} \mathrm{SO}_{4}$ has a relatively high melting point: $884^{\circ} \mathrm{C}$, but traces of metals like $\mathrm{V}, \mathrm{Ca}, \mathrm{Pb}, \mathrm{W}$ decrease it.)

b) $\mathrm{Na}_{2} \mathrm{SO}_{4}$ further fluxes the natural protective layers of $\mathrm{Cr}_{2} \mathrm{O}_{3}$ on the super-alloys at imperfections in the $\mathrm{Al}_{2} \mathrm{O}_{3}$ coatings, exposing the underlying active metal to an anodic attack by the oxidizing sulfates and possibly the diffusing oxygen.

c) Like in most localized attacks of noble alloys, this attack preferentially takes place along grain boundaries that become chromium-depleted and further represent potential sites for crack initiation.

This kind of corrosion is not typical of the heavy fueled turbines in which the firing temperatures are purposedly limited and the ash chemistry strongly modified. 
6.2 CORROSION BY VANADIUM-CONTAINING EUTECTICS. - When vanadium is present in the fuel there are additional corrosion risks associated to $\mathrm{V}_{2} \mathrm{O}_{5}\left(\mathrm{MP}=675^{\circ} \mathrm{C}\right)$ and its fusible sodium salts quoted above [9]. Furthermore, there is an eutectic in the $\mathrm{Na}_{2} \mathrm{SO}_{4} / \mathrm{V}_{2} \mathrm{O}_{5}$ system [10]; from a practical point of view, figure 4 shows the "sticking temperature" of $\mathrm{V}_{2} \mathrm{O}_{5}-\mathrm{Na}_{2} \mathrm{SO}_{4}$ slags, defined as the "lowest temperature at which an ash deposit will adhere to a metallic surface" [11]. The mechanism involved is also an electrochemical attack in molten slags.

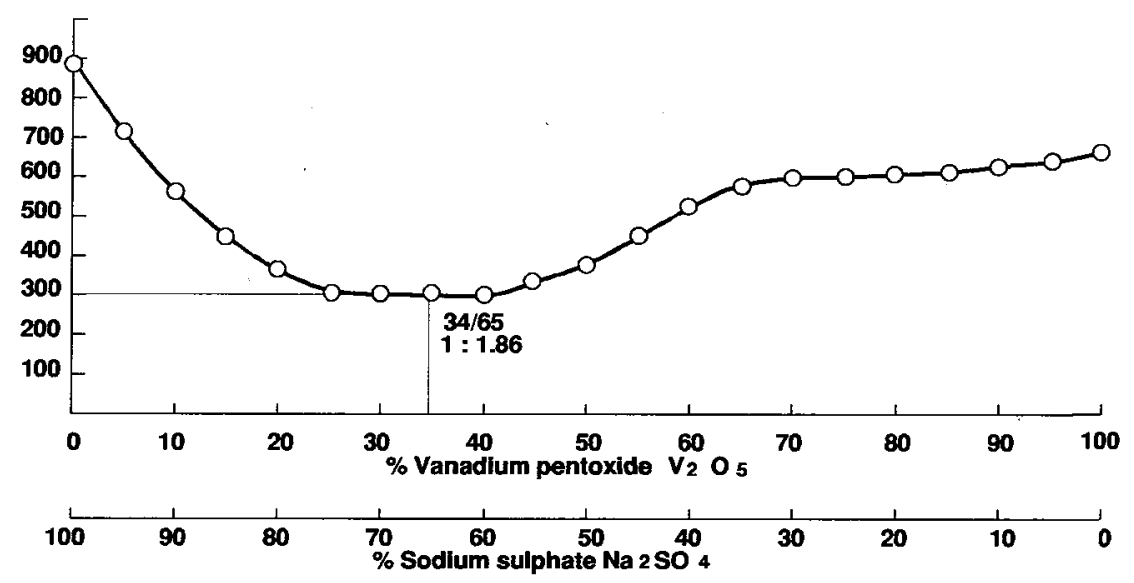

Fig. 4. - The "sticking temperature" of $\mathrm{Na}_{2} \mathrm{SO}_{4} / \mathrm{V}_{2} \mathrm{O}_{5}$ mixtures.

6.3 THE COUNTER-MEASURES. - The sulphidation corrosion risk is generally controlled by: i) a limitation of the firing temperature and ii) a strict control of the alkaline metal concentration in the fuels ( $\mathrm{Na}+\mathrm{K}<1 \mathrm{ppm}$ by weight), which is achieved, if necessary, by extracting the salts in "wash water". Chromium-based inhibitors are sometimes used too.

Vanadium contents exceeding $0.5 \mathrm{ppm}$ must be inhibited. In this respect, magnesium compounds have been early identified as efficient "ash-modifiers". Downstream of the flames, magnesium reacts with $\mathrm{V}_{2} \mathrm{O}_{5}$ in a way similar to sodium, to form a variety of salts or "mixed oxides":

$\mathrm{MgO}+\mathrm{V}_{2} \mathrm{O}_{5} \rightarrow \mathrm{MgV}_{2} \mathrm{O}_{6}$ : magnesium metavanadate; $\mathrm{MP}=740^{\circ} \mathrm{C}$

$2 \mathrm{MgO}+\mathrm{V}_{2} \mathrm{O}_{5} \rightarrow \mathrm{Mg}_{2} \mathrm{~V}_{2} \mathrm{O}$ : magnesium pyrovanadate; $\mathrm{MP}=930^{\circ} \mathrm{C}$

$3 \mathrm{MgO}+\mathrm{V}_{2} \mathrm{O}_{5} \rightarrow \mathrm{Mg}_{3} \mathrm{~V}_{2} \mathrm{O}_{8}$ : magnesium orthovanadate; $\mathrm{MP}=1070{ }^{\circ} \mathrm{C}$

The $\mathrm{MgO}-\mathrm{V}_{2} \mathrm{O}_{5}$ diagram is given in figure 5 [12].

Furthermore, if one takes into account the consumption of magnesium due to the formation of $\mathrm{MgSO}_{4}$, one must inject practically four times the quantity of magnesium required by the stoichiometry of the orthovanadate $(\mathrm{Mg} / \mathrm{V}=0.71)$. This corresponds to a $\mathrm{Mg} / \mathrm{V}$ ratio of about 3 by weight.

Except in a reduced number of cases, this ratio of 3 is now widely applied as it has proven the optimum dosage to fully control the vanadic corrosion and limit the fouling by ashes; it has become therefore the "inhibition orthodoxy" [13]. 


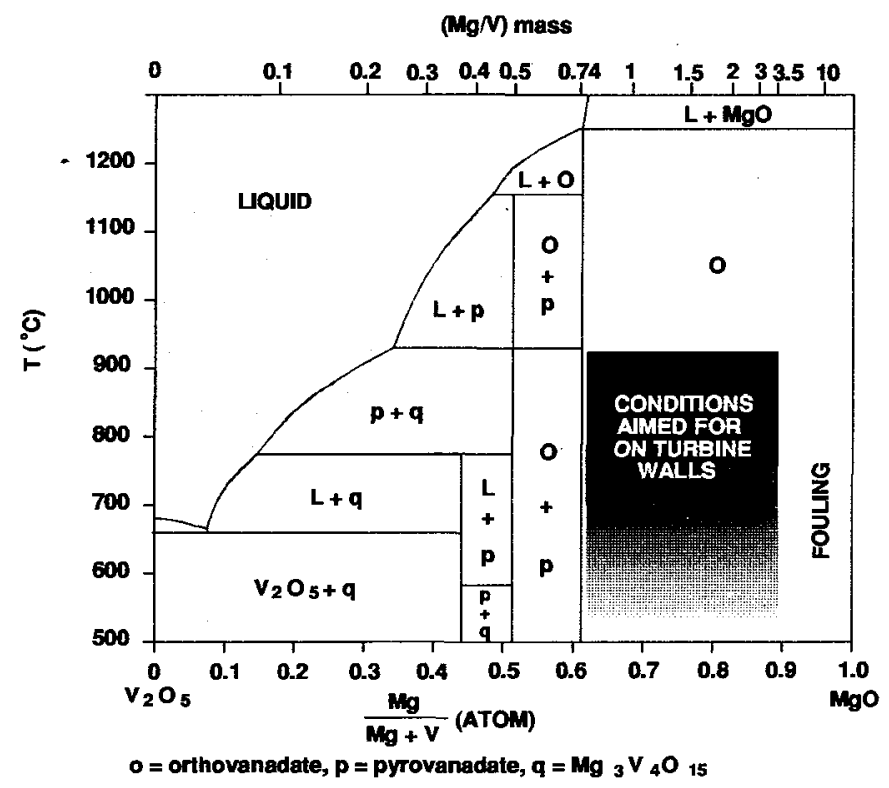

Fig. 5. - The $\mathrm{MgO} / \mathrm{V}_{2} \mathrm{O}_{5}$ diagram after [12].

An important feature is the reversibility of the magnesium sulphidation reaction in the turbine path, the dissociation of $\mathrm{MgSO}_{4}$ into $\mathrm{MgO}$ being controlled by the temperature and the $\mathrm{SO}_{3}$ partial pressure $[14,15]$ :

$$
\mathrm{MgO}+\mathrm{SO}_{3} \Leftrightarrow \mathrm{MgSO}_{4}
$$

$K_{1}(T)=\left(P_{\mathrm{SO}_{3}}\right) 1=2.39 \times 10^{8} \exp (-33 \times 200 / T)$

$P_{\mathrm{SO}_{3}}$ is controlled itself by the $\mathrm{SO}_{3} / \mathrm{SO}_{2}$ equilibrium already discussed:

$$
\begin{gathered}
\mathrm{SO}_{2}+1 / 2 \mathrm{O}_{2} \leftrightarrow \mathrm{SO}_{3} \\
K_{2}(T)=\left(P_{\mathrm{SO}_{3}}\right) /\left(P_{\mathrm{SO}_{2}} \times\left(P_{\mathrm{O}_{2}}\right)^{1 / 2}\right)=1.557 \times 10^{-5} \exp (11655 / T), \\
\quad(\text { for } 900<T<1500 \mathrm{~K})
\end{gathered}
$$

The partial pressure $P_{\mathrm{SO}_{2}}$ can be calculated, using the mass balance, from the sulphur content of the fuel (Cs), the air-to-fuel ratio and the total gas pressure [15]. For a frame $9 \mathrm{E}$ turbine operating full-load in the ISO conditions, this leads to:

$$
\left(P_{\mathrm{SO}_{3}}\right)_{\text {in GT }}=0.2241 \times \mathrm{Cs} /\left(1+4.785 \times 10^{4} \exp (-11655 / T)\right)
$$

The formulae (3) and (4) show that $\mathrm{MgSO}_{4}$ is stable only below $960^{\circ} \mathrm{C}$ in the turbine path, for a fuel containing $2 \%$ sulphur. This is the reason why one finds stratified ashes on the first stage parts (Fig. 6), with $\mathrm{MgSO}_{4}$ present near the walls and $\mathrm{MgO}$ in the external part 


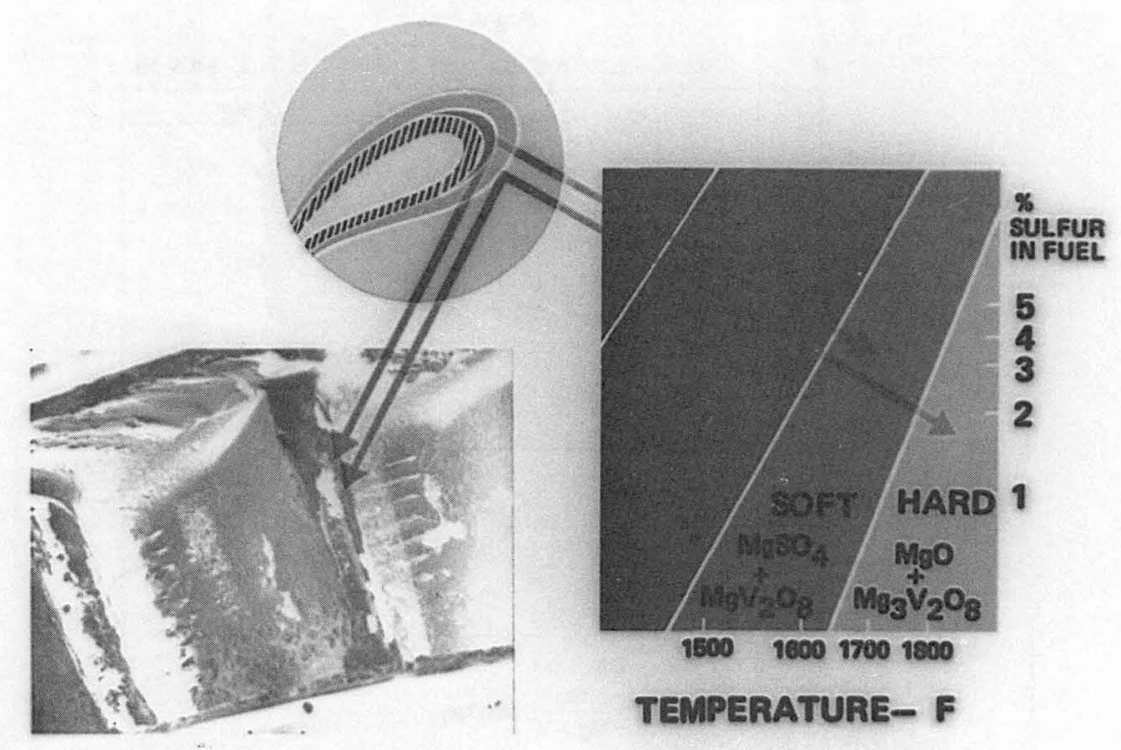

Fig. 6. - Stratified deposits on a first stage nozzle (Courtesy of GE).

of the deposit. Deposit stratification also results from changes in fuel composition and firing temperature.

In fact, magnesium sulphate is a helpful by-product, as its dissolution during water washing brings about the collapse of the deposit layers (despite the insolubility of $\mathrm{Mg}_{3} \mathrm{~V}_{2} \mathrm{O}_{8}$ and $\mathrm{MgO}$ ), the totality of the ashes being thus carried away by the water stream.

\section{The basics of fuel oil treatment plant ("FOTP").}

A FOTP performs the basic processes needed to prepare the ash(forming fuel for gas turbine use (Figs. 7 and 8):

- heating to lower the fuel viscosity to a suitable level;

- filtration to remove the sediments;

- "water washing" to remove the earth and earth-alkaline metals;

- dosing a Mg-based additive to inhibit vanadic corrosion.

1) Filtering represents a key-treatment alongside the whole FOTP as particles are a potential source of various problems: they can damage the pumps and the "flow-dividers"; they can erode the fuel nozzles (and consequently dangereously distort the fuel atomization patterns) as well as the turbine components. It is essential to stress the "monitoring" part played by the filters as for the general fuel quality: unfortunately, this latter function is often not fully percieved.

2) In water-washing, the alkaline and earth-alkaline metals are transferred into the water phase through an intimate mixing process. The thinly dispersed, salt-laden water is then removed either by centrifugal force or by gravity using electrostatic force to coalesce the tiny water droplets. Several stages are often required. The separation is assisted by "demulsifiers", 


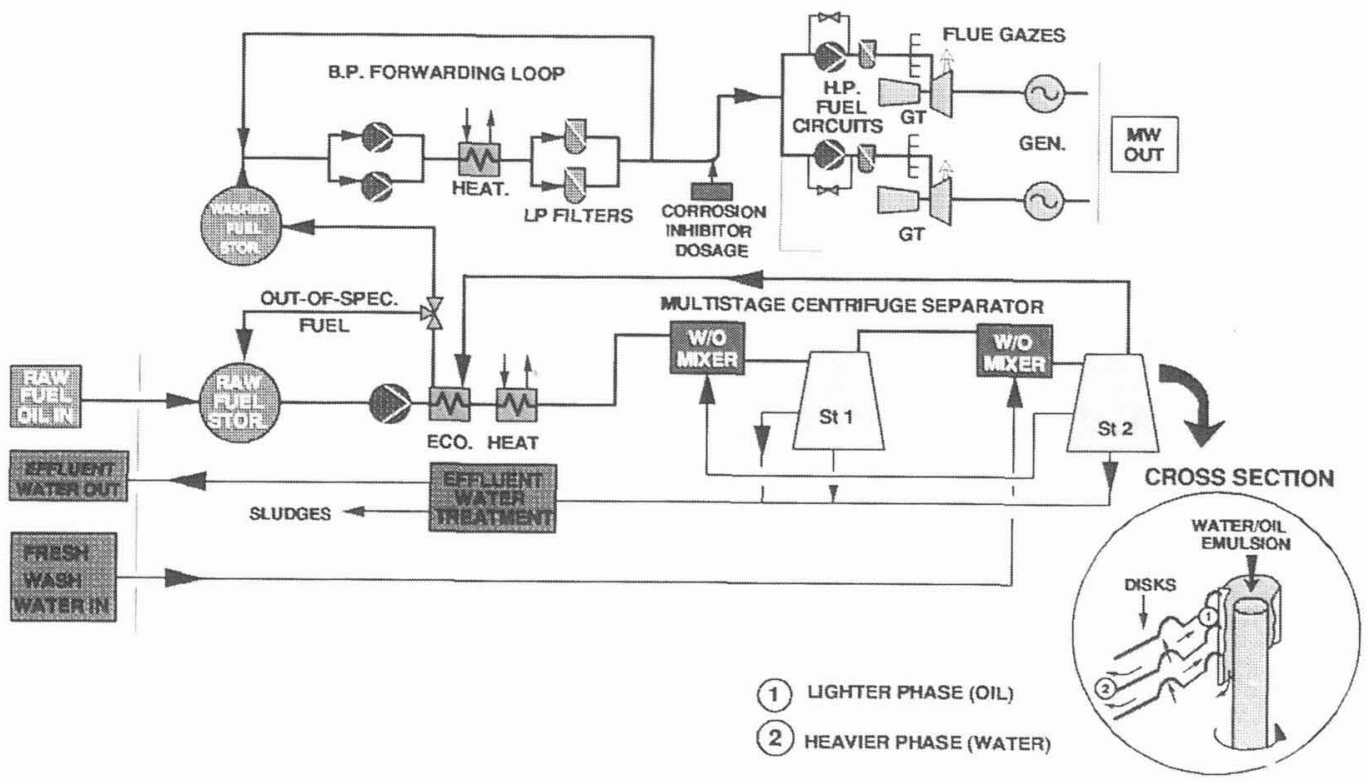

Fig. 7. - Fuel oil treatment plants based on centrifuge separators.

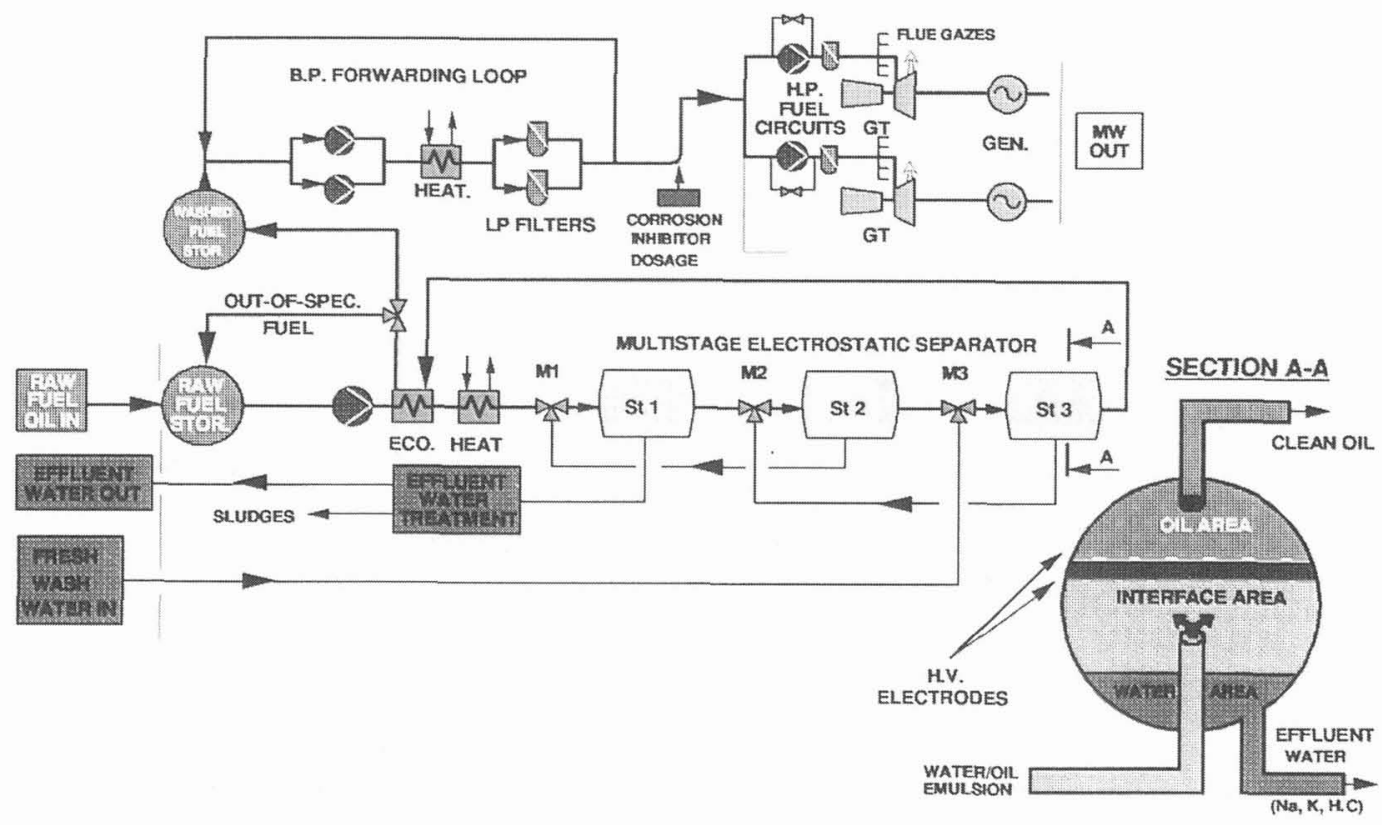

Fig. 8. - Fuel oil treatment plant based on electrostatic separators. 
sophisticated surfactant molecules that adsorb onto the interfacial layers of the droplets and embrittle them, even when present in low concentrations (5-50 ppm).

3) The dosage of $\mathrm{Mg}$ additives is presently performed on-line. Nowadays, oil-soluble magnesium inhibitors are used in preference to water-soluble ones (magnesium sulfate) and to "magnesium slurries" (magnesium hydroxide), due to decisive advantages: high purity, homogeneous mixing, no abrasive effect, etc.

\section{Practical experience on ash-forming fuels.}

There are worldwide a number of power plants based on heavy fueled gas turbines [16, 17]. Most EGT SA's experience lies in the Middle-East: Qatar, Iraq, Saudi Arabia... (crude oils), in North-Africa: Morroco (heavy oil) and in Asia: Pakistan (blended heavy oil), China (crude oil). Table I gives the characteristics of several power plants of this type with the metal contents of the corresponding fuels. A peculiarity of the Chinese crude oils lies in the considerable amount of nickel in comparison with vanadium.

Table I. - Except of EGT SA experience on ash-forming fuels.

\begin{tabular}{|c|c|c|c|c|c|c|}
\hline $\begin{array}{l}\text { COUNTRYI } \\
\text { UTLLITY NAME }\end{array}$ & LOCATION & $\begin{array}{c}\text { TUREINE } \\
\text { FRAME/ } \\
\text { NUMBER OF } \\
\text { UNITS }\end{array}$ & $\begin{array}{l}\text { TYPE OF } \\
\text { FUEL }\end{array}$ & $\begin{array}{c}\text { FIRING } \\
\text { TEMPERATURE }\end{array}$ & $\begin{array}{l}\text { TOTAL FRED } \\
\text { HOUUS } \\
\text { (1/1992) }\end{array}$ & $\begin{array}{l}\text { TYPACAL METALS } \\
\text { CONCENTRATIONS } \\
\text { IN THE FUELS (pPM) }\end{array}$ \\
\hline $\begin{array}{l}\text { MORROCO/ } \\
\text { O.N.E. }\end{array}$ & $\begin{array}{l}\text { AGADIR } \\
\text { TANGIER } \\
\text { TETUAN }\end{array}$ & MS5001P/6 & HEAVY (E.D.) & $\simeq 900^{\circ} \mathrm{C}$ & 170000 & $\begin{array}{c}\mathrm{Na}+\mathrm{K}=52 \\
\mathrm{~V}=66\end{array}$ \\
\hline $\begin{array}{l}\text { CHINA*I } \\
\text { H.I.P.D.C. }\end{array}$ & SHANTOU & MS6001B/2 & CRUDE (C.D.) & $\simeq 1100^{\circ} \mathrm{C}$ & $>40000$ & $\begin{array}{c}\mathrm{Na}+\mathrm{K}=21 \\
\mathrm{~V}=3.5, \mathrm{Ni}=20.3\end{array}$ \\
\hline $\begin{array}{l}\text { PAKISTAN/ } \\
\text { W.A.P.D.A. }\end{array}$ & KOT ADDU & MS9001E/4 & $\begin{array}{l}\text { BLENDED } \\
\text { RESIDUAL } \\
\text { (E.D.) }\end{array}$ & $\simeq 1025^{\circ} \mathrm{C}$ & $>45000$ & $\begin{array}{c}\mathrm{Na}+\mathrm{K}=50 \\
\mathrm{~V}=52, \mathrm{NI}=20\end{array}$ \\
\hline
\end{tabular}

Heavy fueled machines require careful monitoring of fuel treatment processes and a strict maintenance schedule that in turn ensure good operation reliability.

During operation, the fuel entering the turbine is routinely analysed in order: i) to measure the water and sediment contents; ii) to check the sodium, potassium, vanadium, and nickel concentrations (generally by emission spectrometry). This is to ensure that the alkaline metals have been properly removed and that a suitable magnesium-to-vanadium ratio is being applied.

Periodical ash removal are effected too, either by injection of slightly abrasive, combustible materials (nutshells) in the running machine or by water-washing, after shut-down. The 
output and efficiency performances of the machines are thus restored. The turbine is also to some extent self cleaned by stop and restart cycles: the hygroscopic $\mathrm{MgSO}_{4}$ contained in the deposits absorbs humidity during shut-downs and forms hydrates $\mathrm{MgSO}_{4}, x \mathrm{H}_{2} \mathrm{O}(x=6$ or 7) that flake and spall when they undergo the thermal shocks caused by a start-up.

Chemical and crystallographic analyses of the ashes are regularly performed to check the modification of the ashes proceeds correctly and to provide a better understanding of the deposit chemistry. Indeed the build-up of a data base gathering fuel oil and ash analysis is of prime interest for both the gas turbine manufacturer and the user.

Table II. - Examples of crystallographic patterns of ash deposits collected from first stages.

\begin{tabular}{|c|c|c|c|c|}
\hline $\begin{array}{c}\text { X-RAY } \\
\text { DIFFRACTION } \\
\text { SIGNALS }\end{array}$ & A & $\mathbf{B}^{*}$ & c & $\mathbf{c}^{\mathbf{n + m}}$ \\
\hline MAJOR PHASES & $\begin{array}{r}\mathrm{CaSO}_{4}, 2 \mathrm{H}_{2} \mathrm{O} \\
\mathrm{Mg}_{3} \mathrm{~V}_{2} \mathrm{O}_{8}\end{array}$ & $\begin{array}{c}\mathrm{MgSO}_{4}, 7 \mathrm{H}_{2} \mathrm{O} \\
\mathrm{NiSO}_{4}, 7 \mathrm{H}_{2} \mathrm{O}\end{array}$ & $\begin{array}{c}\mathrm{MgSO}_{4}, 7 \mathrm{H}_{2} \mathrm{O} \\
\mathrm{MgSO}_{4}, 6 \mathrm{H}_{2} \mathrm{O} \\
\mathrm{Mg}_{3} \mathrm{~V}_{2} \mathrm{O}_{8}\end{array}$ & $\begin{array}{c}\mathrm{MgSO}_{4} \\
\mathrm{Mg}_{3} \mathrm{~V}_{2} \mathrm{O}_{8}\end{array}$ \\
\hline MDDLE PHASES & & $\mathrm{MgNiO}_{2}$ & & MgO \\
\hline TRACE PHASES & $\begin{array}{l}\mathrm{Ni}_{3} \mathrm{~V}_{2} \mathrm{O}_{8} \\
\mathrm{MgNiO}_{2}\end{array}$ & $\mathrm{Ni}_{3} \mathrm{~V}_{2} \mathrm{O}_{8}$ & & $\mathrm{MG}_{2} \mathrm{~V}_{2} \mathrm{O}_{7}$ \\
\hline
\end{tabular}

* NICKEL IS THE MAJOR METALLIC CONTAMINANT OF THE FUEL.

* DEPOST "C" GLOWED AT $1000^{\circ}$ C FOR 1 h (IN THE LAB)

Table II shows some of the results of these analyses. The deposits A and $\mathrm{B}$ are actual deposits while the deposit $\mathrm{C}^{\prime}$ is obtained by glowing the deposit $\mathrm{C}$ at $1000^{\circ} \mathrm{C}$ for 1 hour. Their crystallographic patterns show that a lack of $\mathrm{MgSO}_{4}$ and an excess of $\mathrm{MgO}$ can be taken to be a sign of abnormal over-heatings.

\section{Conclusion.}

Despite the complexity of the ash chemistry in the hot gas path of a turbine, a strict control of the fuel quality $(\mathrm{Na}+\mathrm{K}<\mathrm{l} \mathrm{ppm})$ and of the inhibitor dosage $(\mathrm{Mg} / \mathrm{V}>3)$ together with a limitation of the firing temperature makes the reliable operation of such power plants possible. Maintaining a data base of fuels and deposits analyses is of interest from a practical and a theoretical viewpoint. 


\section{References}

[1] BRANDT D.E., ColaS M., A new advanced technology $50 \mathrm{hz}$ Gas Turbine, paper 90 GT6338 (ASME, June 1990).

[2] BISSEAUd J.M., Planners: think gas turbines !, Gas Turbines Congress, paper AGTR 8806 (Cannes, 1988).

[3] MOLIĖRE M., COLAS M., Water-in-fuel emulsions to reduce the NOx emissions of gas turbines, $\mathrm{Nr} 5$ (Gec Alsthom technical review, 1991), pp. 47-58.

[4] STAMBleR B., Gas turbine world (Nov-dec. 1991) pp. 26-29.

[5] BROMBley A.F., Gas turbine fuel treatment: the reasons why, Petrolite pamphlet (April 1986).

[6] SChILKe P.W., Foster A.D., PePe J.J., Advanced G.T. materials, GER 3569B (Gas Turbine Library, October 1988).

[7] TiSsoT B., Characterisation of heavy crude oils and petroleum residues (Technip, Paris, 1984) pp. 3-18.

[8] BARTOK W., SAROFIM A.F., Fossil fuel combustion (J. Whiley and Son Eds., 1991).

[9] LORDI F.D., For longer life, improved performances: advanced materials and coatings, Gas Turbines Congress, paper Nr 3 (Deauville, 1984).

[10] MAY W.R., et al., Ind. Eng. Chem. Prod. Res. Dev. 12 (1973) 140-145.

[11] WICKERT K., Oelfeuer tech. (July 1961) 10-13.

[12] SPERANSKAYA E.I., Bull. Head Sci. USSR Inorg. Mat. 7 (1971) 605-608.

[13] GREENLEe R., Vanadium inhibition orthodoxy, Petrolite pamphlet (November 1989).

[14] KNOPf H.J., Staude H., Z. Phys. Chem. 204 (1955) 265-275.

[15] LAY K.W., Trans. ASME (Apr. 1974) 134-137.

[16] HERGOTT C., Gas turbine fuels, Gas Turbines Congress, AGTR-8805 (Cannes, 1988).

[17] LUCCHINI J., Operation experience with crude, heavy and residual oils, paper EGT/M-JL 2802 (EGT SA Library, February 1992). 